\title{
Bewogen Zorg
}

Citation for published version (APA):

Geesink, R. G. T. (1998). Bewogen Zorg. Univesitaire Pers Maastricht. https://doi.org/10.26481/spe.19980911rg

Document status and date:

Published: 11/09/1998

DOI:

10.26481/spe.19980911rg

Document Version:

Publisher's PDF, also known as Version of record

\section{Please check the document version of this publication:}

- A submitted manuscript is the version of the article upon submission and before peer-review. There can be important differences between the submitted version and the official published version of record.

People interested in the research are advised to contact the author for the final version of the publication, or visit the DOI to the publisher's website.

- The final author version and the galley proof are versions of the publication after peer review.

- The final published version features the final layout of the paper including the volume, issue and page numbers.

Link to publication

\footnotetext{
General rights rights.

- You may freely distribute the URL identifying the publication in the public portal. please follow below link for the End User Agreement:

www.umlib.nl/taverne-license

Take down policy

If you believe that this document breaches copyright please contact us at:

repository@maastrichtuniversity.nl

providing details and we will investigate your claim.
}

Copyright and moral rights for the publications made accessible in the public portal are retained by the authors and/or other copyright owners and it is a condition of accessing publications that users recognise and abide by the legal requirements associated with these

- Users may download and print one copy of any publication from the public portal for the purpose of private study or research.

- You may not further distribute the material or use it for any profit-making activity or commercial gain

If the publication is distributed under the terms of Article $25 \mathrm{fa}$ of the Dutch Copyright Act, indicated by the "Taverne" license above, 
074

Universiteitsbibliotheek

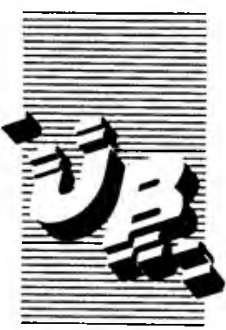

De uitleentermijn verstrijkt op:

\section{OKT. 1998}

Universiteit Maastricht

Postbus 616

6200 MD Maastricht

Gelieve deze publicatie tijdig te retourneren of (telefonisch) verlenging van de uitleentermijn aan te vragen. 


\title{
Bewogen Zorg
}

dr. R.G.T. Geesink

\author{
Rede \\ uitgesproken bij aanvaarding \\ van het ambt van \\ gewoon hoogleraar orthopaedie \\ aan de \\ Universiteit Maastricht
}

11 september 1998 


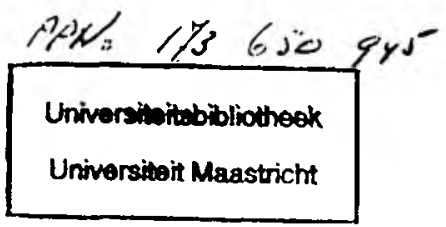

(C) dr. R.G.T. Geesink, Maastricht 1998

Universitaire Pers Maastricht

ISBN 90-9012001-7 


\section{Bewogen zorg}

Mijnheer de rector, geachte aanwezigen,

Honderd jaar geleden, op 26 maart 1898, verscheen een oproep in het Nederlands Tijdschrift voor Geneeskunde, bestemd voor artsen met bezigheden op het gebied der "orthopaedie, geneeskundige gymnastiek en massage" teneinde te komen tot een beroepsvereniging. Aldus geschiedde en zo werd op 1 mei 1898 werd in het Amsterdamse café Parkzicht bij het Vondelpark de Nederlandse Orthopaedische Vereniging (NOV) opgericht. De NOV is daarmee de op één na oudste orthopaedische wetenschappelijke vereniging ter wereld. Alleen de American Orthopaedic Association ging haar hierin voor, in 1887. Wie zou denken dat de Nederlandse orthopaedie daarmee ook kan bogen op een lange academische traditie heeft het evenwel mis.

Academische erkenning van de orthopaedie vond pas plaats in 1961 met de benoeming te Nijmegen van professor San Giorgi tot eerste hoogleraar orthopaedie in Nederland. Andere universiteiten volgden en zo ook werd Ton van der Linden in 1979 de eerste hoogleraar orthopaedie aan deze universiteit.

De orthopaedie in Nederland is volwassen geworden in de periferie van grote categorale klinieken als ondermeer de Annakliniek te Leiden, de Cornelis Vroege Stichting te Alblasserdam en de St. Maartenskliniek te Nijmegen. De orthopaedie heeft daarbij van meet af aan met beide benen in de maatschappij gestaan en zich aldaar een niet weg te denken plaats verworven. 
Zo zijn klachten en aandoeningen van het bewegingsapparaat een der meest frequente in de eerste lijn en is gewrichtsslijtage de belangrijkste chronische ziekte. Voorts zijn in onze hoog geindustrialiseerde matschappij arbeidsongeschiktheid en invaliditeit in tenminste $30 \%$ der gevallen te herleiden tot aandoeningen van het bewegingsapparaat. Een jaarlijks bedrag van tien miljard gulden is hiermee gemoeid. Een wat duale positie dus, maatschappelijk al lang volwassen maar academisch nog in de puberteit. De academische tak van de orthopaedie, als vak gesymboliseerd door de boom die met steun van een paal recht op groeit, heeft die steun dan ook zelf nog wel enige tijd nodig alvorens haar volle rendement aan universiteit en maatschappij te kunnen leveren. Ik zal $U$ in het navolgende enige beelden schetsen van de orthopaedie van vandaag, gefundeerd op een lange traditie, maar met de blik gericht op de toekomst.

We kunnen hierbij niet voorbij gaan aan het feit dat het karakter van het vak aanmerkelijk veranderd is. Orthopaeden waren aanvankelijk vooral bezig met de behandeling van restgevolgen van polio, tuberculose, hematogene osteomyelitis, aangeboren afwijkingen en late gevolgen van traumatische letsels. Een effectieve behandeling van ouderdomsaandoeningen als arthrose van heup of knie was nog maar zeer beperkt mogelijk, om over preventie nog maar niet te spreken. Mensen mochten al blij zijn als zij met een stok nog enigszins mobiel bleven en verder van achter de geraniums de wereld aan zich voorbij konden laten trekken. Betrekkelijk geruisloos is er toch veel veranderd. 
Onze senioren, zo heten ze tegenwoordig, zijn van achter de geraniums vandaan gekropen en maken zich tegenwoordig eerder druk hoe al het ijzerwerk in hun lichaam zich zal gedragen in de detectorpoortjes op onze vliegvelden. Op straat zie je krukken hooguit in gebruik na ongevalsgevolgen alwaar de orthopaed ook al veel meer actieve inbreng heeft gekregen, decimeters hoge schoenvoorzieningen zijn nog maar zelden nodig en ernstige bochels zie je alleen nog maar op schilderijen in musea. Ook op het gebied van preventie is veel veranderd. Door tijdige screening en behandeling van ondermeer heupaandoeningen hoeven onze baby's niet meer op middelbare leeftijd invalide te worden door premature gewrichtsslijtage.

Ook de maatschappelijke visie op leven en bewegen is geleidelijk aan veranderd. Door stijging van welvaart en vorderingen in de geneeskunde is de gemiddelde levensverwachting in onze westerse wereld aanmerkelijk toegenomen. En hoewel orthopaedie als vak zelf weinig bijdraagt aan levensverlenging, breekt toenemend het besef door dat het weinig zin heeft leven te verlengen indien dat niet gekoppeld wordt aan voldoende kwaliteit van leven. Zelfstandig bewegen en functioneren is daarbij een belangrijk aspect en de eisen daaraan gesteld nemen snel toe, mede onder invloed van beeldvorming in de media. Mobiliteit is een kernbegrip in onze huidige maatschappij, waarbij de filosofische basis geleidelijk lijkt te verworden van "Cogito, ergo sum" tot "Moveo, ergo sum". Van "Ik denk, dus ik ben" tot "Ik beweeg, dus ik ben". De orthopaed vervult hierbij in toenemende mate de rol van "qualy-maker". 
In de beeldvorming rond de hedendaagse orthopaedie wordt dat nog het best gesymboliseerd door de heupprothese, hoewel we uiteraard veel meer te bieden hebben. Inderdaad is met het succes van de heupprothese onder invloed van sir John Charnley in Engeland in de jaren zestig de toon voor de moderne orthopaedie gezet. Hoewel het idee van gewrichtsvervanging door een kunstgewricht al eeuwenoud was, wist Charnley als een ware hybride van clinicus en techneut een aantal wezenlijke beperkingen te overwinnen en daarmee de operatie van totale heupvervanging te transformeren van onvoorspelbare gok tot wetenschappelijk voorspelbaar succes. Zijn belangrijkste bijdragen waren de introductie van botcement voor de fixatie van de prothese aan bot, voorts de keuze van poly-ethyleen als lager materiaal voor het gewricht tussen kop en kom, terwijl eveneens de basis vorm van de prothese onderdelen werd vastgelegd.

De technologische revolutie kreeg vat op de orthopaedie en in het verlengde hiervan kwamen biomechanica en biomaterialen als wetenschappelijke disciplines tot ontwikkeling. Waar de biomechanica zich vooral bezighoudt met de fysische interacties in het lichaam en eventueel daarin geplaatste implantaten, is de focus van de biomaterialen wetenschap vooral gericht op de biologische interactie tussen lichaam en biomateriaal, dat wil zeggen elk materiaal dat in het lichaam geplaatst wordt ter vervanging van een van haar functies. Beide disciplines spelen een cruciale rol in de verdere ontwikkeling van de moderne implantaten. Deze beperken zich al lang niet meer tot heup en knie, hoewel de successen aldaar nog steeds niet geëvenaard worden 
door gewrichtsvervanging van bijvoorbeeld schouder, elleboog, pols, vinger of enkel gewricht om van de wervelkolom nog maar niet te spreken.

Implantatie van een kunstgewricht in bijvoorbeeld de heup brengt met zich mee dat de versleten heupkop verwijderd wordt en vervangen door een kop met steel die in het bovenbeen verankerd wordt. De kop van metaal beweegt in een kom van gewoonlijk polyethyleen kunststof die op haar beurt weer in het bot van het bekken word vastgezet. Een hechte verbinding tussen prothese en bot is daarbij noodzakelijk aangezien de krachten op zo'n gewricht aanzienlijk zijn. Zo kunnen bij normale dagelijkse activiteiten als opstaan uit een stoel of trap aflopen, al krachten in de heup optreden tot zesmaal die van het lichaamsgewicht.

Pas met de introductie van het botcement (poly-methylmethacrylaat of PMMA) door Charnley in het begin der zestiger jaren gelukte het een stabiele verbinding te bewerkstelligen tussen prothese en bot. Botcement is een soort tweecomponenten kunststof die na menging in circa tien minuten uithardt en daarbij alle kieren en spleten tussen prothese en bot opvult. Een goede krachtsverdeling over het gehele prothese oppervlak wordt daarmee mogelijk. Grote successen zijn hiermee behaald, met name bij oudere patiënten en patiënten met rheumatoide arthritis, over het algemeen patiënten categorieën die geen zware inspanningen verrichten. Succes werkt evenwel aanstekelijk waardoor de neiging bestaat de indicaties voor een dergelijke operatie uit te breiden totjongere patiënten met gewrichtsbeschadiging door ook andere oorzaken. 
De patiënt van vandaag is mondig, dank zij de media volledig op de hoogte van de technische mogelijkheden en accepteert geen beperking in zijn leefwereld meer en zeker niet gedurende de beste en meest actieve jaren van zijn leven. Ze realiseren zich evenwel te weinig dat we hier toch wel tegen de grenzen van het mogelijke aan lopen. Volgens de literatuur voldoet een gecementeerde heupprothese uitstekend bij vrouwen boven de zeventig jaar. Nu komt arthrose van het heupgewricht meer bij vrouwen dan mannen voor, maar er zijn toch vele patiënten bij wie de resultaten wat tegen vallen.

Oorzaken hiervoor zijn ten dele wel aan te geven. Botcement wordt (te) warm tijdens uitharden, is chemisch niet zo inert als we wel graag zouden willen en ook haar sterkte gaat achteruit in de tijd. Dat leidt tot breuken in het cement waardoor beweging tussen prothese en bot ontstaat. Beweging tussen prothese en bot veroorzaakt botverlies, waarna mede onder invloed van slijtageprodukten van de bewegende prothese onderdelen een vicieuze cirkel ontstaat van toenemende pijn en botverlies met uiteindelijk ook klinisch falen van de prothese. Een revisieoperatie wordt nodig en hoewel moderne or thopaeden daar steeds bedrevener in worden blijven dat grote en kostbare ingrepen die beter voorkomen kunnen worden door het gebruik van betere primaire protheses. Met name voor jonge en aktieve patiënten is lang gezocht naar alternatieve methoden van prothesefixatie, liefst zonder gebruik van botcement.

Met de ontwikkeling van moderne biomaterialen heeft zich een nieuwe ontwikkelingsgolf aangediend in de prothesechirurgie, waarvan het eind nog lang niet in 
zicht is. Voor skelettoepassingen zijn in het bijzonder de calciumfosfaten interessant gezien hun chemische verwantschap met de botmineralen.

Hoewel de calciumfosfaten als zodanig door hun mechanische eigenschappen niet geschikt zijn als prothese dragermateriaal is het door het aanbrengen van een dunne laag hydroxyapatiet (HA) op een metalen protheseoppervlak wel mogelijk dat bot zich direct met de prothese verbindt. Als zodanig vormden HA-coatings de eerste generatie bioactieve biomaterialen. Bioactief hier omschreven als gewenst positieve interactie met bot. Door zijn botvriendelijke eigenschappen kan hydroxyapatiet kieren en spleten tussen prothese en bot opvullen door bot als het ware naar de prothese toe te leiden. Een evenwichtige krachtsverdeling tussen prothese en bot wordt hiermee mogelijk, zonder een botcement als tussenlaag

Deze vruchtbare samenwerking tussen de afdeling biomaterialen van professor de Groot, destijds in Amsterdam, en de afdeling orthopaedie van het academisch ziekenhuis Maastricht leidde in 1986 tot een wetenschappelijke wereldprimeur, waarbij het me een genoegen was tien jaar geleden mijn proefschrift over dit onderwerp op dit zelfde podium te verdedigen. Het is een dankbare gedachte dat vandaag de dag wereldwijd honderdduizenden patiënten met dergelijke implantaten rondlopen en daar hun voordeel mee doen.

De resultaten zijn zeer bemoedigend. De eerste honderd patiënten uit onze kliniek hebben een "survival rate" na tien jaar van $97 \%$ voor de femoraal component. 
Dat dan bij een groep relatief jonge patiënten met een gemiddelde leeftijd van 54 jaar. Dat is aanzienlijk beter dan we op grond van bijvoorbeeld Zweedse epidemiologische statistieken met meer conventionele methoden zouden mogen verwachten. Deze goede resultaten zijn inmiddels bevestigd door multicenter trials in zowel Europa als de Verenigde Staten, hoewel de follow-up daar enkele jaren achterloopt op de onze.

Toch is er geen reden om op onze lauweren te rusten. Door toepassing van deze bioactieve implantaten is een meer fundamenteel inzicht ontstaan in de wezenlijke processen die botaanmaak sturen. Hierdoor is het mogelijk gebleken een nieuwe generatie coatings te ontwikkelen, gebaseerd op biomimetische principes. Hierbij wordt het proces van de vorming van natuurlijke botkristallen geimiteerd. Deze mikrokristallijne coatings hebben hierdoor een nog hogere biologische activiteit dan de inmiddels meer conventionele plasma-spray coatings. Dit is evenwel nog maar een deel van de winst. Door het precipitatie procédé in vloeistof is het mogelijk zeer complexe structuren driedimensionaal adequaat te coaten. Ook vindt het procédé bij kamertemperatuur plaats, in plaats van bij $10.000^{\circ} \mathrm{C}$, waardoor het mogelijk wordt om biologisch actieve stoffen in de coating op te nemen. Dit opent geheel nieuwe perspectieven door bijvoorbeeld coatings met antibiotica bij de behandeling of profylaxe van implantaat infecties of combinaties met groeifactoren als BMP's (botmorphogenetische proteïnes) die de behandeling van bijvoorbeeld botverlies in de implantaat revisiechirurgie een geheel nieuwe dimensie geven. Voor tbouwend op eerder werk dienen zich dus geheel nieuwe mogelijkheden aan. 
Toch is niet alles rozegeur en maneschijn. Een heupprothese ondergaat een tot meerdere miljoenen belastingscycli per jaar, en dat zowel meer als ook zwaarder naarmate patiënten jonger zijn. Waar geen auto of machine tien jaar zonder onderhoud kan functioneren zal het niet verbazen dat de nog resterende problemen met name te herleiden zijn op slijtage van de gebruikte lager materialen. Cobalt-chroom als kopmateriaal in combinatie met poly-ethyleen voor de kom is lang de standaard geweest. Keramische kopmaterialen hebben weliswaar verbetering maar geen oplossing gebracht terwijl nieuwere technieken als volledig keramische of metalen lagers de experimentele fase nog niet te boven zijn en waarschijnlijk om meerdere redenen ook niet die oplossing zullen zijn die men daarvan verwacht. Over enkele jaren worden gewrichtslagers volgens geheel nieuwe technologieën verwacht, gebruik makend van ultraharde of zachte materialen. Het is niet uitgesloten dat de prothesiologie daarmee wederom een forse stap voorwaarts zal zetten.

Komt de perfecte prothese met onbeperkte levensduur daarmee in zicht? Een prothese die niet meer los gaat en niet meer slijt? De uiteindelijke triomf van de techniek waarbij kunst beter wordt dan natuur??? Voor onze steeds talrijkere patiënten is het te hopen, maar vraagtekens blijven er helaas nog te over. Protheses kunnen nog steeds uit de kom schieten, infecteren, de operatie kan een soms zelfs dodelijke vetembolie of thromboembolische complicatie tot gevolg hebben, er. kunnen abnormale verkalkingen rond de prothese ontstaan en er kunnen zich complicaties met zenuwen of bloedvaten voordoen. 
Ook een beoogde gelijke beenlengte na operatie wordt niet altijd gerealiseerd. Al deze problemen worden ieder weliswaar in procent of promille uitgedrukt, maar alles bij elkaar toch geen kleine groep. Sommige van deze problemen kunnen weliswaar farmacologisch beïnvloed worden, maar het middel is soms erger dan de kwaal.

Waar de implantaten zelf technisch steeds beter worden, blijkt de zwakke schakel in toenemende mate de chirurg zelf te zijn in samenhang met patiënt gebonden factoren. Variaties in de anatomie van de patiënt tezamen met variaties in de ligging van de patiënt op de operatietafel maken de ligging van de prothese onderdelen soms minder optimaal. Wanneer dit in extreme mate het geval is kan dat al kort na operatie problemen geven, bijvoorbeeld in de vorm van een luxatie, waarbij de kop uit de kom schiet. Wanneer dit in meer subtiele mate het geval is treden problemen pas na vijf à tien jaar op in de vorm van voortijdige gewrichtslagerbeschadiging. Bij onze revisie operaties blijkt in circa $40 \%$ der gevallen sprake te zijn van impingement, dat wil zeggen het aanlopen van de hals van de prothese tegen de rand van de kom, met schade aan het lager als gevolg. In het bijzonder geldt dit voor onze jonge en meer actieve patiënten. Dit draagt dan in belangrijke mate bij aan de verkorte levensduur van zo'n prothese, ongeacht soort of type. Ook hier bestaan nieuwe mogelijkheden zoals computer-assisted surgery, waar we recent aan werken.

Voor opererende robots hoeven we vooralsnog niet echt bang te zijn, Robodoc uit de jaren tachtig staat al bijna in het museum. Wat wel aanzienlijke toegevoegde waarde heeft is navigatiehulp tijdens operaties. 
Net als een piloot onder moeilijke omstandigheden op zijn navigatie-instrumenten blind kan vliegen, kan ook de orthopaed (en overigens niet alleen deze) computers te hulp roepen om de accuratesse van plaatsbepaling in het lichaam te verbeteren. Zo kan bij skeletimplantaten met behulp van computernavigatie de ligging van de implantaten zowel vóór als tijdens het inbrengen gecontroleerd worden aan de hand van preoperatieve CT-scans die gekoppeld worden aan oppervlakte anatomische kenmerken van de patiënt. Dat alles driedimensionaal real-time en nog gecorrigeerd voor intraoperatieve beweging van de patiënt. Verscheidene grote operaties in de orthopaedie kunnen door dergelijke "virtual reality" technieken verder geoptimaliseerd worden met gunstige effecten op accuratesse en complicatie percentages. Voorts zijn beperktere incisies mogelijk met als gevolg daarvan weer verminderde morbiditeit en kortere opnameduur. In technische zin inderdaad een triomf der techniek. Een volgende stap naar steeds minder invasieve benadering van steeds grotere operaties.

Toch moeten we ons bij al deze successen realiseren dat een gewrichtsvervangende operatie eigenlijk niet meer is dan een moderne vorm van amputeren, waarvan we de gevolgen kunstig weten te maskeren. Eigenlijk is het een heel onlogische oplossing. Waarom zouden we de gehele femurkop met een deel van de hals daarvan verwijderen en vervangen door een kop en steel die tot zowat halverwege het bovenbeen reikt als de oorspronkelijke aandoening beperkt is tot slechts enkele millimeters van het gewrichtskraakbeen van de heup. Preventie of vroegbehandeling zou dan ook de voorkeur 
verdienen, maar van de gewone gewrichtsslijtage of wel arthrose weten we ondanks grote successen in haar behandeling in meerderheid nog steeds de oorzaak niet. We missen nog steeds een basaal inzicht in de processen die leiden tot arthrose, laat staan haar pathofysiologie die ons inzicht geeft in het feit waarom een ogenschijnlijk zelfde gewricht bij de ene patiënt wel een progressieve slijtage ondergaat en bij een andere niet. Of ook waarom arthrose, zelfs binnen één patiënt, in slechts dertig procent dubbelzijdig is.

Een soortgelijk verhaal zou ik kunnen vertellen over de mogelijkheden tot behandeling van rugaandoeningen als scoliose, kyfose, degeneratie of trauma. Er zijn hier de laatste decennia grote vorderingen gemaakt in operatieve correctie en stabilisatie mogelijkheden waardoor patiënten sneller en beter weer in de maatschappij geïntegreerd kunnen worden. Maar ook hier geldt dat we vandaag de dag nog steeds de essentie van lage rugpijn of scoliose niet begrijpen. Als aetiologie en diagnose al niet zonneklaar zijn, hoe weten we dan of onze behandeling wel adequaat is. De enige manier om hier verbetering in aan te brengen is terug te gaan naar de basis. Wil de orthopaedie een wezenlijke verdere vooruitgang boeken in de behandeling van onze moderne welvaartsziekten, zullen we eerst een meer fundamenteel begrip omtrent basale zaken als arthrose, rugpijn en dergelijke moeten verkrijgen.

Mogelijk is de balans de laatste decennia te veel doorgeschoten in de richting van de techniek, mede ook door de invloed van een krachtig medisch-industrieel complex met onvoldoende tegenwicht van academische 
research. We zullen meer oog moeten krijgen voor de natuurlijke reparatieprocessen in onze weefsels, als bot kraakbeen of spierweefsel. Er gloort hier weliswaar licht aan de horizon dankzij vorderingen in de moleculaire biologie hoewel er nog een lange weg te gaan is alvorens dit op eenvoudige wijze klinisch toepasbaar zal zijn.

Vanaf het begin heeft het onderzoek van onze afdeling zich ondermeer gericht op arthrosebehandeling. Hoewel de techniek van prothese implantaties en verbetering daarvan een prominente rol spelen zijn we ons tevens bewust geweest van de beperktheid daarvan en hebben zwaar ingezet op biochemisch en biologisch onderzoek naar aetiologie en pathofysiologie van arthrose in zijn vroegste verschijningsvormen. In het verlengde hiervan ligt onderzoek naar meer biologisch getinte methoden van kraakbeen reparatie.

Kraakbeen is een uniek weefsel met een specifieke ruimtelijke oriëntatie en materiaal samenstelling. Er zijn collagene vezels van een specifiek type II dat alleen in gewrichtskraakbeen voorkomt in combinatie met een specifieke samenstelling aan proteoglycaan eiwitten die door hun molecuul grootte binnen het collagene netwerk gevangen zitten, door hun hydrofiele eigenschappen water aantrekken en daardoor verantwoordelijk zijn voor de vast elastische spanning van kraakbeen. Wanneer door welke oorzaak ook collagene vezels beschadigd raken of door metabole invloeden de molecuul grootte van de proteoglycaan eiwitten daalt, treedt lekkage van deze eiwitten op en start een vicieuze cirkel van verder verval. Eenmaal verloren is er geen natuurlijke reparatie van zelfde kwaliteit te verwachten. 
Daarbij is een reserve voorraad kraakbeen voor transplantatie doeleinden in het lichaam niet in voldoende mate voorhanden zoals dat met bot in zekere mate nog wel het geval is. Kraakbeen is avasculair wat betekent dat een reparatie mechanisme maar zeer beperkt en langzaam mogelijk is aangezien alle materiaal transport slechts via diffusie door de synoviale membraan kan plaatsvinden. In de praktijk is het afbraakmechanisme veelal sterker dan het beperkte regeneratiepotentieel en is het fibrocartilaginaire regeneraat toch niet opgewassen tegen de krachten in het gewricht. Dat eindigt dus veelal bij een kaal gewricht, waarbij alleen radicale chirurgie in de vorm van een prothese nog oplossing kan brengen.

Willen we verder komen zullen we in een vroege fase het arthrotisch proces moeten detecteren. Uit onderzoek op onze afdeling is gebleken dat er biochemische markers zijn die al in een vroege fase prognostisch significant zijn. Probleem in de praktijk is dat patiënten in een vroege fase van arthrose nog maar weinig tot geen klachten hebben. Als er al klachten zijn, laat aanvullende noninvasieve beeldvormende diagnostiek ons nog steeds in de steek. Ook met moderne MRI technieken is het nog maar zeer beperkt mogelijk een betrouwbare kwantificeerbare indruk van kraakbeen te verkrijgen. Zelfs bij invasieve meting via arthroscopie is dit nog steeds problematisch. Ook hier zal nog het nodige werk moeten worden verzet.

Blijft de vraag naar meer biologisch georiënteerde methoden van kraakbeenreparatie, liefst in een fase vóór uitgebreide operaties nodig zijn. We kunnen dan denken aan medicamenten die, al of niet lokaal toegediend, 
verdere afbraak blokkeren of aanmaak van nieuwe kraakbeeneiwitten stimuleren. Voorts worden stoffen onderzocht die ingrijpen op het niveau van de beschadigde collagene vezels. Ook in meer biologisch georiënteerde operatietechnieken zit wel vooruitgang. In het verleden gebruikte technieken als transplantatie van periost of perichondrium hebben toch niet dat succes gebracht dat daarvan werd verwacht. Hierbij wordt bijvoorbeeld een stuk bekleding van het ribkraakbeen in een kraakbeen defect geplaatst, in de gedachte dat hierin aanwezige kraakbeen cellen weer tot gewrichtskraakbeen konden uitgroeien. Hoewel vroege resultaten in een beperkte indicatie groep zeker wel goed zijn, treedt later toch vaak weer degeneratie of verkalking op. Dit betekent dat de geregeneerde chondrocyten toch niet op de juiste wijze functioneren en dat het milieuinterne van een gewricht toch aanzienlijk complexer blijkt dan gedacht. Dergelijke technieken, inclusief heterologe of autologe chondrocyten transplantaties na laboratorium opwerking, hebben tot op heden dus nog geen blijvend succes gebracht.

Uitgangspunt bij al deze methoden zijn hoog gedifferentieerde kraakbeencellen die normaliter in het lichaam nauwelijks nog tot celdeling in staat zijn. Voor vermenigvuldiging van deze kraakbeencellen is het nodig dat zij tijdelijk dedifferentiëren en na voldoende multiplicatie weer naar kraakbeencellen differentiëren. Dit heen en weer getransformeer werkt niet en eindigt in de praktijk veelal in een blijvend gededifferentiëerde celpopulatie die geen bruikbare functie meer heeft. Een alternatieve route vormt natuurlijke differentiatie van in het lichaam nog aanwezige primitieve cellen naar kraakbeencellen. 
In ons beenmerg circuleren gedurende ons gehele leven stamcellen die in verschillende types verantwoordelijk zijn voor aanvulling van onze perifere bloedcellen wanneer die door natuurlijk verloop verloren gaan. $\mathrm{Zo}$ zijn er ook cellen die kunnen differentiëren in de richting van bot en/of kraakbeen en dit opent geheel nieuwe perspectieven voor weefselreparatie. Via een beenmerg punctie wordt celmateriaal verkregen dat in het laboratorium voldoende vermenigvuldigd wordt waarna het op een geschikte tijdelijke drager in het lichaam wordt gereplanteerd en aldaar verder groeit.

Experimentele resultaten met dergelijk door tissueengineering verkregen materiaal laten zien dat dit bot na zes weken al tweemaal zo sterk is als autoloog getransplanteerd bot, de gouden standaard bij bottransplantaties tot nu toe. Aangezien het alleen om laboratorium bewerking van patiënteigen materiaal gaat zijn er geen afstotings- of andere immunologische problemen te verwachten en al evenmin problemen met potentiële overdracht van ziektekiemen als HIV of hepatitis die de bruikbaarheid van heteroloog transplantatiemateriaal in de toekomst in toenemende mate zullen gaan beperken. Ook ethische problemen als met xenotransplantaties worden hiermee omzeild.

Met bot lukt dit experimenteel al heel redelijk en de verwachting is dat deze technieken binnen enkele jaren hun intrede in de kliniek zullen doen. Kraakbeen is wat complexer, maar fundamenteel niet wezenlijk anders, zodat we vooralsnog optimistisch blijven over de toekomst hiervan. Zie hier de principes van "tissue engineering", een nieuw soort biologische reparatie- 
geneeskunde, dat de komende jaren het aanzicht van niet alleen de orthopaedie aanzienlijk zal veranderen. Het verschil tussen "kunst" en "eigen" vervaagt hierbij in toenemende mate, aangezien het om laboratorium bewerking van lichaamseigen materiaal gaat waarbij we een restitutio ad integrim van oorspronkelijk verloren gegaan weefsel nastreven met de idee dat herstel hiervan duurzamer is dan met onze huidige kunstproducten.

Op zich klinken al die biotechnologische ontwikkelingen heel fraai, hoewel zij bij sommigen mogelijk ook wel associaties wekken met luchtkastelen. Dat betreft dan uiteraard de financiering van dergelijk onderzoek. Het biomaterialen onderzoek van onze afdeling heeft nooit uitgebreide financiële middelen ontvangen van de universiteit en heeft zijn huidige positie dan ook in belangrijke mate op eigen kracht bewerkstelligd. Dat lukt tegenwoordig best redelijk. Biomaterialen en biotechnologie onderzoek staan vandaag de dag samen met informatica genoteerd als branches met de grootste economische groei perspectieven. Het is dan ook niet zo problematisch om financiering voor onderzoek te vinden, maar ook daar kleven bezwaren aan. Niet alleen van principieel ethische aard als het om industrie gesponsord onderzoek gaat. Het kweekt misschien wel een wetenschapper, die zijn produkt goed weet te verkopen en daar ook nog van kan leven, terwijl hij en passant met de revenuen en royalty's zijn aan de beurs genoteerde onderzoeksinstituut aan de gang weet te houden. Bezwaar blijft dat de in het begin al zo nodig geachte integratie van orthopaedie in een academische setting van multidisciplinair onderzoek en onderwijs achterwege blijft. 
De kern van het probleem is niet zozeer dat orthopaedisch onderzoek niet rendabel zou zijn. Het probleem is meer algemeen, namelijk dat de baten van innovatie niet in de geneeskunde zelf terug komen. De winst komt terecht in de maatschappij als geheel die dat vaak nog niet eens als zodanig herkent, laat staan erkent. $\mathrm{Nu}$ is er uiteraard niets mis met maatschappelijk dienstbetoon voor een dienstbaar vak als geneeskunde. Wel volledig mis is dat door een dergelijk eenrichtingsverkeer van onderzoeksgelden bij zowel overheid als financiers van gezondheidszorg het idee ontstaat dat innovatie in de geneeskunde niet rendabel is en alleen maar een bodemloze put voor wetenschappelijke hobbyisten is.

Een aardig voorbeeld hiervan is de arthroscopische behandeling van meniscusletsels in de knie. Tot voor zo'n jaar of twintig geleden was het gebruikelijk dat een beschadigde meniscus via een klassieke operatie werd behandeld wat toendertijd al snel tien dagen ziekenhuisopname inhield. Nu geschiedt dat via een in de volksmond als "inkijkoperatie" bekend staande methode poliklinisch ambulant. En passant is het gemiddelde ziekteverzuim hierdoor terug gebracht van tenminste drie maanden tot luttele weken. Arbeidsongeschiktheidverzekeraars tel uit je winst, maar hoge investeringskosten voor het ziekenhuis. De kosten worden nog verder opgejaagd door een substitutie-effect, zolang er nog wachtlijsten bestaan. De vrijkomende capaciteit wordt immers gebruikt om de produktie op te voeren. In het bedrijfsleven een volstrekt eerbare zaak, maar door de methode van financiering van gezondheidszorg aldaar eerder een straf op kwaliteitsverbetering. 
De verandering bij een meniscusoperatie is slechts een willekeurig voorbeeld. Ook bij de eerder genoemde totale heupoperatie is de gemiddelde opnameduur door allerlei maatregelen en verbeterde technieken in dezelfde periode teruggebracht van vier weken naar zeven dagen en hoeft de eerder genoemde patiënt met een wervelkolomstabilisatie door betere, maar helaas ook duurdere, implantaten geen drie maanden meer in een gipskorset te liggen, maar kan deze al na tien dagen het ziekenhuis lopend verlaten en zo de draad van opleiding of beroep weer oppakken. Allemaal voorbeelden van behandelingen waarbij het ziekenhuis en daarmee de gezondheidszorg in het algemeen voor de hogere kosten gesteld worden, maar macro-economisch grote voordelen behaald zijn. Niet alleen in kwaliteit van leven maar ook puur financieel. Het probleem is alleen dat het financieel voordeel in de zakken verdwijnt van arbeidsongeschiktheidsverzekeraars en andere uitkeringsverstrekkers. Ondertussen groeien hun beurskoersen evenredig met onze wachtlijsten en moeten de ziekenhuizen maar zien hoe ze hun innovatie financieren.

Bij deze wachtlijsten doen zich ook enkele op zijn minst merkwaardige fenomenen voor. Dat wachtlijsten de maatschappij veel geld kosten, spreekt vanzelf. De werkgevers die dat tegenwoordig zelf moeten betalen hebben dat al lang uitgerekend en zijn daarom gaarne bereid te investeren in wachtlijstverkorting omdat hen dat alleen maar geld oplevert. En dan bijvoorkeur alleen voor eigen werknemers. Echter, ook bij de oudere patiënt levert een heup of knie operatie de maatschappij op termijn meer op dan de ingreep zelf kost. Daarbij dan nog geheel afgezien van de kwaliteit van leven. 
Er is door gezondheidseconomen berekend dat het eenmalig $f 546$ miljoen gulden kost om de wachtlijsten te saneren, waarna wel enige structurele ophoging nodig zal zijn om dat ook zo te houden. Anderzijds beweren de werkgevers dat zij jaarlijks meer dan één miljard gulden schade lijden als gevolg van de wachtlijsten, waarvan alleen al $f 900$ miljoen aan orthopaedische oorzaken. Wanneer deze schadeposten ten gunste van de zorgsector zouden worden aangewend zouden niet alleen alle werknemers adequaat geholpen kunnen worden, maar ook alle vroegere werknemers die deze bedrijven hebben geholpen groot en rijk te worden. Het argument van geldgebrek is dan ook in het geheel niet valide. Politieke durf is hier meer nodig dan geld. En al evenzeer ligt hier de conclusie voor de hand dat de budgettering en bezuinigingsrondes van de afgelopen decennia misschien een iets goedkopere geneeskunde hebben opgeleverd, maar wel macro-economisch aanzienlijke schade hebben aangericht.

Investeren in een moderne geneeskunde op marktconforme wijze georganiseerd is overlevings noodzaak. Zaken als producttypering en diagnose-behandelcombinaties dienen van de grond te komen en gefinancierd te worden op basis van reële kosten en niet op basis van fictieve tarieven die sinds twintig jaar alleen nog maar procentsgewijs en dan meestal benedenwaarts zijn bijgesteld, in het geheel geen rekening houdende met technische ontwikkelingen. Daarbij dient het budget de patiënt en zijn zorg te volgen. Alleen dan kunnen ziekenhuizen realistisch concurreren in kwaliteit en daar ook voor beloond worden. Het alternatief is dat er inderdaad een tweedeling ontstaat en niet alleen onze 
miljonairs met hun kapitaal naar het buitenland vluchten maar ook onze actieve mondige en kapitaalkrachtige patiënten zich als eersten in het Europa met open grenzen buitenlands zullen gaan laten behandelen, te beginnen hier aan het eind van de straat.

Een adequaat financieringsmodel is overigens allerminst de enige oplossing voor de huidige problemen. Ook de beroepsgroep zelf draagt verantwoordelijkheid om de zorg betaalbaar, efficiënt en toegankelijk te houden. Vele initiatieven zijn hier ontplooid door de zorgsector. Zo is door de Maastrichtse orthopaediegroep met de groep huisartsgeneeskunde het project specialistenconsultatie in de huisartspraktijk gedaan. De bevindingen zijn verwerkt in een proefschrift van collega Vierhout en ook elders gepubliceerd. Wanneer een dergelijk systeem landelijk zou worden ingevoerd is berekend dat zoiets alleen al voor de orthopaedie een besparing van $f 42$ miljoen jaarlijks zou opleveren door minder noodzakelijke verwijzingen. Het nascholingseffect van zo'n systeem word dan ook nog buiten beschouwing gelaten. Het laat duidelijk zien dat alternatieve samenwerkingsvormen het onderzoeken waard zijn en de geneeskunde zowel beter als goedkoper kunnen maken. Het is dan wel schrijnend te moeten constateren dat de minister van VWS desondanks de academische huisartsgeneeskunde financieel in de steek dreigt te laten.

Ook binnen de tweede lijn zelf dienen we ons bij voortduren bewust te zijn van zin of onzin van bestaande en toekomstige behandelingen. Willen we ons vak betaalbaar en toegankelijk houden en tevens meegaan met nieuwe ontwikkelingen zullen we alle zeilen moeten 
bijzetten om te voorkomen dat het vak aan zijn eigen succes ten ondergaat, daarbij geholpen door de aandacht van de media voor alle nieuwe ontwikkelingen die de medische consumptie alleen maar verder opstoken. Het is de taak van de medische beroepsgroep al deze ontwikkelingen in goede banen te leiden. Consensus groepen zoals die in Nederland onder coördinatie van het $\mathrm{CBO}$ functioneren zijn een goede start in de richting van een evidence-based soort geneeskunde, toegespitst op de Nederlandse situatie. Voorbeelden zijn de consensus groepen zoals die al functioneren voor totale heupprothese, arthroscopie, thrombose profylaxe, rugklachten en radiculair syndroom. $\mathrm{Zij}$ kunnen de efficiency van diagnostiek en behandeling opvoeren en daarbij de arts enerzijds beschermen tegen claims wegens nalatig handelen, anderzijds een wal opwerpen tegen de ongebreidelde maar niet altijd relevante vraag van patiënten naar nieuwe technologie.

Goede documentatie van medisch handelen is in dit opzicht ook van eminent belang. Zo is door de NOV, op initiatief van de Nijmeegse academische kliniek, een landelijke implantaat registratie opgezet, beheerd door de SIG, waarin de gegevens van alle in Nederland geimplanteerde heup en knieprotheses worden vastgelegd. Een en ander werd mede onder invloed van politieke druk geëntameerd na de debacles met brekende hartkleppen en lekkende siliconenborstprotheses. Ook kunstgewrichten, hoe goed ook, zijn niet feilloos en een goede traceerbaarheid is dus in ons aller belang. Nog maar enkele jaren geleden werd de orthopaedische gemeenschap opgeschrikt door slechte resultaten van een nieuw soort botcement. 
Theoretisch een goed onderbouwd verhaal, praktisch een ramp die gelukkig grotendeels aan Nederland voorbij is gegaan, maar alleen tijdig opgemerkt kon worden door een sluitende registratie van onze Scandinavische collega's. De opzet van een dergelijk systeem is geen geringe zaak en door vele betrokkenen is daar veel tijd, geld en moeite in gestoken. Hoewel bijna ter ziele door onvoldoende rugdekking van overheid en verzekeraars is inmiddels een overbruggings-financiering toegezegd waarmee haar toekomst hopelijk gered kan worden. In Scandinavie is al bewezen dat dergelijke registraties kwaliteitsverbetering en kosten-besparing genereren door eliminatie van protheses met slechte resultaten en terugkoppeling van resultaten tot op het niveau van de individuele orthopaed.

Ook in de logistieke sfeer is verbetering nog wel mogelijk, zoals verdere verkorting van verpleegduur. Dit is goed mogelijk, hoewel een deel van de benodigde aanvullende zorg uit thuiszorg en verpleeghuissector moet komen. De problemen in deze sectoren hoef ik hier niet nader aan te duiden. Een overmaat aan regelgeving door de overheid op dit terrein maakt een en ander ook al niet eenvoudiger. Analoge argumenten gelden voor stroomlijning van noodzakelijk diagnostisch onderzoek alvorens het behandeltraject te openen. Het creëren van een vlot en efficiënt diagnose- en behandeltraject, een "lean medical machine", is evenwel wezenlijk om de toenemende stroom van niet alleen orthopaedische patiënten in de toekomst te kunnen blijven opvangen.

Orthopaedie is een groeispecialisme zoals ondermeer vermeld in het RIVM rapport van enkele jaren geleden. 
Een groei met $40 \%$ van ouderdomsaandoeningen wordt voorspeld tot 2010. Dat is $3-4 \%$ per jaar en dat gaat daarna nog door tot minstens 2035 . Hoewel dat mogelijk al na het emeritaat van mijn opvolger valt, zijn de eerste effecten nu al duidelijk merkbaar. We moeten ons daarbij realiseren dat deze oudere bevolkingsgroep een meer dan evenredig beslag op kosten en bedden met zich mee brengt. Een typisch voorbeeld is een frequent voorkomende aandoening als heupfractuur door osteoporose bij de oudere patiënt. Door problemen met thuisopvang of overplaatsing naar verpleeghuis is de gemiddelde opnameduur van een dergelijke heupfraktuurpatiënt nog steeds rond de 26 dagen tegen b.v. 7 dagen voor een normale heupprothesepatiënt. Dit betekent dat elke extra heupfractuur vier prothese patiënten nog langer op hun electieve opname laat wachten terwijl het aanbod in deze categorie eveneens fors toeneemt.

Zo werden in 1995 (laatst bekende cijfers) in Nederland ruim 17.000 primaire heupprothese implantaties verricht en ruim 1500 revisieoperaties. Daarenboven nog 5000 knieprothese implantaties. Volgens voorspellingen zal in 2010 behoefte zijn aan tenminste 25.000 heupprothese implantaties en 4000 revisieoperaties. In de Verenigde Staten is het aantal knieprothese implantaties nu al groter dan het aantal heupprotheses, zodat we in Nederland daar óók nog een behoorlijke inhaalslag kunnen verwachten. Een verdubbeling van het patiëntenaanbod in niet meer dan vijftien jaar, een trend die overigens al vele jaren zichtbaar is maar op dit moment gemaskeerd wordt door de oplopende wachtlijsten. Tevens verklaart dit waarom alle initiatieven tot wachtlijstverkorting nog steeds niet voldoende effect sorteren. 
Deze gevolgen van vergrijzing zijn overigens geen typisch Nederlands probleem, maar worden ook internationaal als zodanig ervaren. Zodanig zelfs dat er een voorstel ligt om de periode 2000 - 2010 uit te roepen tot de "Bone and Joint Decade".

Voor deze aanstaande patiëntengolf is overigens niet alleen geld maar ook man- respectievelijk vrouwkracht nodig. Ook de opleiding van artsen en verpleegkundigen is in Nederland al jaren aan overmatige regulering onderhevig. Gevolg is dat Nederland op dit moment samen met Engeland onderaan de Europese ladder staat met betrekking tot relatieve aantallen orthopaeden. Waar alle artsen en paramedici vandaan moeten komen die zowel de wachtlijsten als de groei door vergrijzing moeten opvangen is mij op dit moment ook nog niet geheel duidelijk, zeker als daar maatschappelijke tendenzen tot vermindering van excessieve werktijden of meer parttime werk bijkomen. Zorgen maak ik me toch wel. Wanneer hier geen coherente lange termijn strategie wordt opgezet wordt dit een van de echte millennium problemen. Wanneer de politiek via een soort handje klap systeem besluit tot 1,3\% (of inmiddels mogelijk iets meer) jaarlijkse stijging van het gezondheidszorg budget, terwijl de wetenschappelijke rapporten in haar eigen bureauladen zowat het dubbele aangeven, is er inderdaad reden tot bezorgdheid. Het is ironisch dat juist door de grote economische groei van de laatste jaren (dit jaar 4\%) het netto percentage van ons bruto nationaal produkt dat aan gezondheidszorg wordt besteed gedaald is van 9,2\% in 1995 tot $8,6 \%$ in 1998 en daarmee wederom een laagterecord in Europa is. Ik betwijfel of we daar echt trots op moeten zijn. 
Protocollering, structurering, maar ook informatie uitwisseling door automatisering kunnen dus veel bijdragen aan het betaalbaar en hanteerbaar houden van onze gezondheidszorg. Toch moeten we daarin ook niet overdrijven. Patiënten blijven individuen die we moeten behandelen met al hun specifieke eigenaardigheden. $\mathrm{Zij}$ worden bovendien terecht steeds mondiger en het valt te verwachten dat in de toekomst een meer actieve rol zal worden weggelegd voor patiëntengroepen en organisaties, waar het gaat om verdeling van de toch beperkte middelen voor gezondheidszorg. Het is een taak van niet alleen politici of medici om uit te maken wat goed is voor onze patiënten.

Voor ons onderwijs gelden analoge argumenten. Ik hoef de deugden van ons probleemgestuurd onderwijs (PGO) hier niet te herhalen, dat gebeurt al genoeg. In een tijd van toenemende medische technocratie moeten we onze studenten blijven duidelijk maken dat we verder moeten kijken dan alleen de kwaal en een medisch-technisch optimaal geprotocolleerde behandeling daarvan. Juist ook een begrip voor de klacht als lichaamstaal kan veelvuldig een gang naar de alternatieve genezer voorkomen. In een tijd waarin het accent steeds meer op de technische aspecten van de geneeskunde komt te liggen blijft het belangrijk ook de meer irrationele aspecten van de geneeskunst niet te verwaarlozen. Dat dan zonder af te glijden naar medisch gesanctioneerde kwakzalverij. Ook geneeskunst is te doceren, maar dan wel door mensen aan het ziekbed of in de spreekkamer. Gelukkig is een goede plaats ingeruimd voor attitudeen vaardigheidstraining, maar toch kan het geen kwaad hier op te blijven hameren in een tijd waar computers 
steeds goedkoper worden en mensen steeds duurder. Een computer is geen alternatief voor een luisterend oor.

In het Maastrichtse onderwijs heeft de orthopaedie van meet af aan haar rol gespeeld hoewel dat wat ruimer zou kunnen gezien haar maatschappelijke relevantie. $\mathrm{Na}$ de theoretische scholing in het bewegingsapparaat via het blokonderwijs maakt de aankomend arts na een facultatief, maar wel populair, keuze co-schap vooral kennis met de praktische orthopaedie in de praktisch medische onderwijs stage, ofwel co-schap. De aanpak is hier nog vrij traditioneel. Introductie op ruimere schaal van probleemgestuurde elementen in het klinisch onderwijs heeft vele voordelen, ook voor de medisch specialistische opleiding. Patiëntgericht handelen houdt in dat we ons ook in het klinisch onderwijs meer richten naar de vraag van de patiënt en niet naar de inhoudsopgave van onze gangbare leerboeken.

Orthopaedisch onderwijs maar ook onderzoek zullen nieuwe stimulansen krijgen door de nieuwe studie Biomedische Technologie, zoals die door de Universiteit Maastricht samen met de Technische Universiteit Eindhoven is opgezet. Anders dan bij het medisch praktisch onderwijs, staat het biomaterialen onderzoek hier in de kern van het thema biologische structuren. De zo nodige verdergaande integratie van bewegingsapparaat onderzoek in het universitaire bestel kan hierdoor zijn beslag krijgen. Bij bewegingsapparaat onderzoek denk ik daarbij niet alleen aan mijn eigen vak, maar ook aan onze collegae chirurgen-traumatologen, reumatologen, revalidatie-artsen en fysiotherapeuten. Tezamen met meer basaal gerichte vakken als anatomie, 
biomechanica, biochemie, biofysica en biomaterialen kan hier een onderzoekscluster ontstaan dat een aanmerkelijk deel van kliniek en prekliniek een solide wetenschappelijke inkadering verschaft. Ook de orthopaedie krijgt hierdoor een nieuwe kans om universitair meer volwassen te worden doordat de driehoek van kliniek, onderzoek en onderwijs nu geheel gesloten wordt.

Dames en heren, ik heb $U$ wat ontwikkelingen geschetst die we de komende jaren kunnen verwachten en hoe we daarop kunnen inspelen. Bij het begin van de volgende honderd jaar orthopaedie en op de drempel van een nieuw millennium lijkt het verleidelijk aan toekomst voorspellingen te doen. Ik heb U echter al overvoerd met nieuwe ontwikkelingen. Bovendien kunnen we alleen extrapoleren vanuit het ons bekende. Meestal levert dat dus niet veel op. Een illustere voorganger bij de American Orthopaedic Association, Henry Mankin, poogde zoiets bij honderd jaar orthopaedie in Amerika te doen. Alle voorspellingen die hij in 1983 voor het jaar 2013 deed waren in 1993 al gerealiseerd en daar waren toch heel gewaagde zaken bij. Wat wel duidelijk is dat het snel gaat en dat we een boeiende tijd tegemoet gaan.

Behoudens geloof in de goede kanten van vooruitgang heb ik hier en daar ook wat zorgen geuit. Dat blijkt ook uit mijn misschien wat cryptische titel "Bewogen Zorg". Orthopaedie verzorgt niet alleen het bewegingsapparaat, maar is zelf ook volop in beweging. Dat geeft conflicten over betaalbaarheid, mankracht en toegankelijkheid. Budgettering versus vernieuwing. Management versus medezeggenschap van artsen en patiënten. 
Protocollering versus individualisering van zorg. Computerisering versus communicatie met de patiënt. Bewogen heeft ook te maken met toegemeten, adequaat en op maat zijn, alsmede afwegen van voor en nadelen van handelen en tenslotte heeft bewogenheid ook een emotionele component. De emotie van de patiënt die niet verloren mag gaan in de onophoudelijke technologische expansie van deze tijd. De bezorgdheid mag evenwel niet gaan overheersen. Er is geen plaats voor fin de siècle pessimisme aan de vooravond van een nieuw millennium. Dat gebeurt al genoeg. We kunnen ook over de drempel van het volgende millennium heenzien als een hergeboorte. Mogelijkheden tot een nieuw evenwicht tussen techniek en natuur, emotie en logica. Ik vertrouw er op dat we met inzet van alle betrokkenen onze Nederlandse gezondheidszorg op dat hoge niveau kunnen handhaven waarom $z i j$ reeds lang bekend is.

Aan het einde van mijn voordracht gekomen is het mij een eer het ambt van hoogleraar orthopaedie aan deze universiteit en dit academisch ziekenhuis te aanvaarden. Ik dank College van Decanen en College van Bestuur voor het in mij gestelde vertrouwen en zie een periode van vruchtbare samenwerking tegemoet. Ook de Raad van Bestuur van azM dank ik voor hun constructieve opstelling gedurende de aanloopfase van mijn nieuwe werkzaamheden. Mijn leermeesters uit het verleden dank ik voor hun inzet. Op hun schouders kunnen wij verder zien dan zij ons gebracht hebben. In het bijzonder dank ik collega orthopaed, wijlen Hans Zwijssen te Dordrecht die mij als aankomend assistent de liefde voor het vak bijbracht. 
Voorts Ton van der Linden die mij opleidde in vrijheid verbonden aan verantwoordelijkheid. Door zijn relativerende en soms sarcastische humor gaf hij ieder zijn plaats binnen de Maastrichtse groep. Evenzeer dank ik medewerkers van het secretariaat, de polikliniek, afdeling, operatiekamers, EHBO, fysiotherapie, trialbureau, management, staf, assistenten en collega's evenals medewerkers van de onderzoekslaboratoria en ondersteunende diensten. Velen van hen hebben vanaf het begin van de academisering van de afdeling orthopaedie in Maastricht hun beste krachten gewijd aan haar opbouw. Ik bedank jullie allen hartelijk en hoop op een voortgezette vruchtbare samenwerking. In het bijzonder ben ik dankbaar dat mijn beide ouders hier nog in goede gezondheid getuige kunnen zijn van mijn aantreden. Zij hebben mij gestimuleerd deze weg op te gaan, vaak met wegcijferen van zichzelf en ik ben hen daar bijzonder dankbaar voor.

Tenslotte Hettie, mijn lieve vrouw en Ingrid, Margriet en Carolien, mijn drie schatten van dochters. Hoewel het soms aantrekkelijk lijkt echtgenote of dochter van een kosmopolitisch wetenschapper te zijn is de prijs in werkelijkheid toch hoog. Het is maar de vraag of jullie zo blij moeten zijn met deze nieuwe carrière gang. Toch denk ik dat we daar samen wel uitkomen en een uitdagende toekomst tegemoet gaan met dit nieuwe avontuur. Het is me een genoegen hier in Maastricht verder aan de slag te gaan. In het enige academische ziekenhuis waar patiënten óp het ziekenhuis liggen en niet alleen carnaval maar zelfs ziek zijn gevierd wordt.

Ik heb gezegd. 



\section{Bibliografie}

dr LF Bakker: de Nederlandse Orthopaedische Vereniging 1898 - 1998. Katwijk, 1998.

RIVM: Volksgezondheid Toekomst Verkenning 1950 - 2010. Sdu, 1993.

CBS: Statistisch Jaarboek 1997. Centraal Bureau voor de Statistiek, Heerlen/Voorburg, 1997.

H. Malchau, P Herberts: Prognosis of Total Hip Replacement. Scientific Exhibit AAOS New Orleans, 1998.

RGT Geesink, M Manley, Editors: Hydroxy-apatite Coatings in Orthopaedic Surgery. Raven Press, New York, 1993.

R Skripitz, P Aspenberg: Tensile Bond between Bone and Titanium. A Reappraisal of Osseo-integration. Acta Orthopaedica Scandinavica, 69: 315-9, 1998.

RGT Geesink, NHM Hoefnagels: Minimum Six Year Results of Hydroxyapatite Coated Total Hip Replacement. J. Bone \& Joint Surgery 77-B: 534-47, 1995. Ten year results submitted.

WL Jaffe: Current Concepts, Total Hip Arthroplasty with HAcoated Prostheses. J. Bone \& Joint Surgery 78-A: 1918-34, 1996.

MR de Leval: Human Factors and Surgical Outcomes, a Cartesian Dream. Lancet 349: 723-5, 1997.

DM Hassan e.a.: Accuracy of Intraoperative Assessment of Acetabular Prosthesis Placement. J.Arthroplasty 13: 80-4,1998.

Nationaal Ziekenhuisinstituut. P de Rooij: Wachtlijsten in Nederlandse Ziekenhuizen, 1998. 
SY Okhuizen, WJA Dhert, LMC Faro, AJP Schrijvers, AJ Verbout: De totale heupprothese in Nederland. Ned Tijdschr v Geneeskd 142; 25: 1434-8, 1998.

SY Okhuizen, WJA Dhert, LMC Faro, JGM Keet, AJP Schrijvers, AJ Verbout: Een raming van de intramurale kosten van plaatsing van een totale heupprothese. Ned Tijdschr v Geneeskd 142; 25: 1450-5, 1998.

E Joosten-van Zwanenburg: Kosten van ziekte en arbeidsongeschiktheid door orthopedische aandoeningen. Institute for Medical Technology Assessment, Erasmus Universiteit Rotterdam, 1996.

A Laupacis, R Bourne, C Rorabeck e.a.: Cost of Elective Total Hip Arthroplasty during the First Year. J. Arthroplasty 9: 481-7, 1994.

C Lavernia, J Guzman, A Gachupin-Garcia: Cost Effectivenes and Quality of Life in Total Knee Arthroplasty. Clinical Orthopedics 345: 134-9, 1997.

WPM Vierhout: Het Gezamenlijk Consult van Huisarts en Specialist in de Eerste Lijn. Proefschrift Universiteit Maastricht 1994.

Editorial: Boneloc - the Christiansen Experience Revisited. Acta Orthopaedica Scandinavica 66: 205-6, 1995.

Consument en Veiligheid: Ongevallen bij Ouderen, 1998.

H. Mankin: Orthopaedics in 2013, a Prospection. J. Bone \& Joint Surgery 65-A: 1190-4, 1983.

Editorial: The Bone and Joint Decade 2000 - 2010. Acta Orthopaedica Scandinavica, 69: 219-20, 1998. 